Türkiye Mesleki ve Sosyal Bilimler Dergisi, Ağustos 2021, Yıl: 3, Sayı: 6, 36-49. Journal of Vocational and Social Sciences of Turkey, Aug 2020, Year: 3, No: 6, 36-49.

ARAŞTIRMA MAKALESİ / RESEARCH ARTICLE

Atıf için /for cited: Ersoy, Y. (2021). Personnel Selection in the Software Industry by Using Entropy-Based EDAS and CODAS Methods. Journal of Vocational and Social Sciences of Turkey, Yll: 3, Sayl: 6, Ağustos 2021, s.36-49.

\title{
PERSONNEL SELECTION IN THE SOFTWARE INDUSTRY BY USING ENTROPY-BASED EDAS AND CODAS METHODS
}

Yusuf ERSOY*

\begin{abstract}
In the global competitive environment, products and services produced in the software industry play a very important role in making businesses more efficient. This situation causes the demand for software industry products and services to increase rapidly. The software industry's ability to serve all businesses regardless of the sector has increased its product range. Especially as the software industry has become open-source code, programming languages have rapidly diversified. This variation has revealed the need for personnel with different qualifications for the software industry. The personnel selection is a complex decision-making process in which multiple criteria and alternatives must be considered simultaneously. This study, it was aimed to select the most suitable software personnel required for a company in the software and consultancy sector using entropy-based EDAS and CODAS methods. In the study, 6 alternative personnel candidates were evaluated according to 6 criteria. The Entropy method was used to determine the weights of the criteria. Criteria weights obtained by the Entropy method were used in EDAS and CODAS methods. The best alternative was identified by comparing the results of EDAS and CODAS methods.
\end{abstract}

Keywords: CODAS, EDAS, Entropy, Personnel Selection, Software Industry.

JEL Classification Codes: C30, C44, C60.

\section{ENTROPİ TABANLI EDAS VE CODAS YÖNTEMLERİ KULLANILARAK YAZILIM SEKTÖRÜNDE PERSONEL SEÇIMI}

\section{ÖZET}

Küresel rekabet ortamında yazılım sektöründe üretilen ürün ve hizmetler işletmelerin daha verimli hale getirilmesinde çok önemli bir rol oynamaktadır. Bu durum yazılım sektörü ürün ve hizmetlerine olan talebin hızla artmasına neden olmaktadır. Yazılım sektörünün sektör gözetmeksizin tüm işletmelere hizmet verebilmesi ürün yelpazesini artırmıştır. Özellikle yazılım sektörünün açık kaynak kodlu hale gelmesiyle programlama dilleri hızla çeşitlenmiştir. Bu çeşitlilik, yazılım sektörü için farklı niteliklere sahip personel ihtiyacını ortaya çıkarmıştır. Personel seçimi, birden fazla kriter ve alternatifin aynı anda dikkate alınması gereken karmaşık bir karar verme sürecidir. Bu çalışmada, yazılım ve danışmanlık sektöründe faaliyet gösteren bir firma için gerekli olan en uygun yazılım personelinin Entropi tabanlı EDAS ve CODAS yöntemleri kullanılarak seçilmesi amaçlanmıştır. Çalışmada 6 alternatif personel aday 6 kritere göre değerlendirilmiştir. Kriterlerin ağırlıklarının belirlenmesinde Entropi yöntemi kullanılmıştır. EDAS ve CODAS yöntemlerinde Entropi yöntemiyle elde edilen kriter ağırlıkları kullanılmıştır. EDAS ve CODAS yöntemlerinin sonuçları karşılaştırılarak en iyi alternatif belirlenmiştir.

Anahtar Kelimeler: CODAS, EDAS, Entropi, Personel Seçimi, Yazılım Sektörü.

JEL Sınıflandırma Kodları: C30, C44, C60.

* (iD Muş Alparslan Üniversitesi, Malazgirt Meslek Yüksekokulu, Dr.Öğr.Üyesi, y.ersoy@alparslan.edu.tr 


\section{TÜRKIYE MESLEKI VE SOSYAL BILIMLER DERGISI}

Türkiye Mesleki ve Sosyal Bilimler Dergisi, Ağustos 2021, Yıl: 3, Sayı: 6, 36-49.

Journal of Vocational and Social Sciences of Turkey, Aug 2020, Year: 3, No: 6, 36-49.

\section{INTRODUCTION}

Human resource management (HRM) is associated with all activities that increase the efficiency of an organization and is considered a strategic component for the competitiveness of the organization. Therefore, in today's competitive business world, companies increasingly pay attention to human resources. Employees in an organization become the most important key source that determines the success of that organization today with their knowledge, skills and motivation (Karabesevic et al., 2018: 55-56).

One of the most important stages in the success of the recruitment process is to reach qualified candidates. All kinds of channels such as the internet, employment offices and newspaper advertisements should be used to reach candidates. After reaching these candidates, it is necessary to choose the most suitable for the job. Hiring inadequate and unqualified personnel can adversely affect the image and success of the company. Choosing the wrong person affects the firm as a lot of time and expense for that person's training and development. Personnel selection is used to prevent this situation and determine the most suitable candidate (Nalbant and Özdemir, 2018: 10).

Personnel selection plays an active role in human resources management. The purpose of personnel selection is to identify candidates or candidates who have the knowledge and qualifications to best fulfill the requirements of the job in an organization. The characteristics of the personnel such as knowledge, skills and experience play a key role in the success of organizations. Decisions to be made about hiring a person are very important for the sustainability and success of the organization. Selecting the best staff from many of alternatives is a Multi-Criteria Decision Making (MCDM) problem (Afshari et al., 2014: 68).

Personnel selection is a complex decision-making process in which many criteria must be evaluated at the same time. The selection process should provide valid and reliable information about alternatives. In the personnel selection process, there are traditional methods such as filling application forms, first interview and test. Recently, these traditional methods are not sufficient for personnel selection. The accuracy of the decisions made by decision-makers using these traditional methods can be argued. Besides, these methods only consider criteria such as age and experience in the decision-making process (Alguliyev et al., 2015: 2). MCDM methods allow the evaluation of alternatives by considering very different criteria.

In this study, it was aimed to select the best software personnel for a company in the field of software and consultancy in Turkey using Entropy-based EDAS and CODAS methods. In the study, criterion weights were calculated with the entropy method, and the alternatives were sorted by the EDAS and CODAS methods.

The rest of the work was organized as follows. In the second part of the study, a literature review was included. The third part includes the hierarchical structure of the study and the methods. The fourth part constitutes the application part of the study. Application results were given in the fifth chapter. In the last part of the study, a general evaluation of the study was made.

\section{LITERATURE REVIEW}

In the literature, it is possible to find many studies in different fields using MCDM methods (Mardani et al., 2015: 516-571; Rezaei, 2015: 766-776; Karabesevic, et al., 2018: 56-57; Mathew and Sahu, 2018: 139-150; Kaplinski et al., 2019: 7-18; Soba et al., 2020: 2-4; Ersoy, 2021: 1805; Ecer et al., 2021: 1156-1160). Some of the studies on personnel selection using MCDM methods in the literature were given in the following paragraphs.

Karabesevic et al. (2015) have used SWARA and ARAS methods for the selection of sales personnel in the telecommunications sector. In the study, four candidates were evaluated according to six 


\section{TÜRKIYE MESLEKI VE SOSYAL BILIMLER DERGISI}

Türkiye Mesleki ve Sosyal Bilimler Dergisi, Ağustos 2021, Yıl: 3, Sayı: 6, 36-49. Journal of Vocational and Social Sciences of Turkey, Aug 2020, Year: 3, No: 6, 36-49.

criteria. Criterion weights were calculated with the SWARA method. Alternatives were ranked using the ARAS method and the most suitable candidate was selected.

Adalı (2016) used EVAMIX and TODIM methods together for personnel selection in the health sector. In the study, five nursing candidates were evaluated according to six criteria. Criterion weights were determined by the AHP method. Criteria weights identified by the AHP method were used in EVAMIX and TODIM methods. The most suitable nurse candidate was selected by comparing the results of EVAMIX and TODIM methods.

Kundakc1 (2016) was used the Gray Relational Analysis method for the selection of software engineer in a technology company. Eight candidates were evaluated according to twelve criteria. In the study, a 5 -scale was used by the company's human resources department to determine the criterion weights. The ranking of the candidates was made according to the results of the Gray Relational Analysis method and the best candidate was selected.

Kenger and Organ (2017) were used Entropy and ARAS methods together for the selection of bank personnel. First, the weights of the criteria were identified by the Entropy method. Five alternative candidates were evaluated according to ten criteria. In the study, the most suitable candidate was determined by ranking the alternatives according to the results of the ARAS method.

Karabesevic et al. (2018) used SWARA and EDAS methods in the process of selecting two system support specialists needed by a company in the information systems sector. Six alternative candidates were evaluated according to seven criteria in the study. The weights of the criteria were calculated using the SWARA method. Alternative candidates were ranked according to the results of the EDAS method and the two most suitable candidates were determined.

Ulutaş et al. (2018) used fuzzy AHP and fuzzy Gray Relational Analysis methods together for the selection of the production planning manager needed by a company that produces automotive parts. In the study, five alternative personnel were evaluated according to five criteria. Criteria weights used in the study were calculated with the fuzzy AHP method. According to the results of the fuzzy Gray Relational Analysis method, alternative personnel were ranked and the most suitable personnel was determined.

İçigen and Çetin (2018) used AHP and TOPSIS methods for personnel selection of a five-star hotel. Ten candidate personnel were evaluated according to fifteen criteria. Criterion weights were calculated using the AHP method. The ranking of the candidates was made using the TOPSIS method and the most suitable personnel were selected.

Tuş and Adalı (2018) were used CRITIC, CODAS and PSI methods together for a textile company personnel selection problem. The weights of five criteria were calculated by using the CRITIC method. Criteria weights calculated by the CRITIC method were used in the CODAS and PSI methods. According to the results of the CODAS and PSI method, seven candidates were ranked and the best candidate was determined.

Samanlioglu et al. (2018) were used fuzzy AHP and fuzzy TOPSIS methods together for the personnel selection of a company's information systems department. Five alternative personnel were evaluated according to thirty criteria. Criterion weights were calculated with the fuzzy AHP method. The ranking of alternative personnel was made using the Fuzzy TOPSIS method and the most suitable personnel was selected

Korkmaz (2019) was used the TOPSIS method for personnel selection in a company in the logistics sector. In the study, nine alternative personnel were evaluated according to six criteria. Alternatives were ranked according to the TOPSIS method results and the best alternative was determined.

Yalçın and Pehlivan (2019) were used fuzzy EDAS, fuzzy COPRAS, fuzzy TOPSIS, fuzzy CODAS, fuzzy WASPAS and fuzzy ARAS and methods together for a manufacturing company personnel 


\section{TÜRKIYE MESLEKI VE SOSYAL BILIMLER DERGISi}

Türkiye Mesleki ve Sosyal Bilimler Dergisi, Ağustos 2021, Yıl: 3, Sayı: 6, 36-49. Journal of Vocational and Social Sciences of Turkey, Aug 2020, Year: 3, No: 6, 36-49.

selection problem. Six alternative personnel were evaluated according to ten criteria. The results of six different MCDM methods were compared and the alternatives were ranked.

Yeni and Özçelik (2019) were used fuzzy CODAS, fuzzy TOPSIS, fuzzy SAW and fuzzy VIKOR methods together for the engineering position of a company. In the study, four candidates were evaluated according to four criteria. Candidates were ranked according to all methods and the most suitable candidate was selected.

Yildirım et al. (2019) were used the ARAS method to select the support personnel required for an airline company. Five alternative personnel were evaluated according to four criteria. According to the results of the ARAS method, alternatives were ranked and the best personnel were determined.

Ulutaş (2019) was used Entropy and MABAC methods for the selection of marketing personnel in a furniture firm. Six alternative candidates were evaluated according to eight criteria in the study. In the first stage of the application, criterion weights were calculated using the Entropy method. Alternative candidates were ranked according to the results of the EDAS method and the most suitable candidate was selected.

Ayçin (2020) was used CRITIC and MAIRCA methods together in the personnel selection process for the information systems department of a firm in the logistics sector. In the study, the weights of seven criteria were determined using the CRITIC method. The best personnel were determined by ranking five alternative personnel using the MAIRCA method.

Madenoğlu (2020) used fuzzy TOPSIS, fuzzy SWARA, fuzzy ARAS, fuzzy Gray Relational Analysis, fuzzy WASPAS, methods for the selection of warehouse supervisor of a production company. Criteria weights used in the study were calculated using the fuzzy SWARA method. Six alternative candidates were evaluated according to six criteria. The most suitable candidate was selected by comparing the results of four different fuzzy MCDM methods.

Taş and Karataş (2021) used neutrosophic AHP and neutrosophic TOPSIS methods for the selection of project manager in a software company. Four alternative personnel were evaluated according to five criteria. Criterion weights were calculated by the neutrosophic AHP method. According to the results of the neutrosophic TOPSIS method, the alternatives were ranked and the best alternative was determined.

\section{METHODS}

Entropy, CODAS and EDAS methods were used in this study. Criterion weights were calculated with the Entropy method, and the alternatives were ranked by CODAS and EDAS methods. Entropy, CODAS and EDAS methods were explained below.

\subsection{Entropy Method}

The concept of Entropy, first proposed by Shannon in 1948, was developed as a weighting method by Wang and Lee in 2009 (Aytekin and Karamaşa, 2017: 75). The Entropy method consists of the following steps (Wang and Lee 2009: 8982; Aytekin and Karamaşa, 2017: 76; Wang et al., 2017: 200201; Ulutaş, 2019: 1558; Dehdasht et al., 2020: 11-12): 


\section{TÜRKIYE MESLEKI VE SOSYAL BILIMLER DERGISi}

Türkiye Mesleki ve Sosyal Bilimler Dergisi, Ağustos 2021, Yıl: 3, Sayı: 6, 36-49.

Journal of Vocational and Social Sciences of Turkey, Aug 2020, Year: 3, No: 6, 36-49.

Step 1: Creation of decision matrix.

There are alternatives in the rows of the $B_{i j}$ decision matrix and criteria in the columns. The decision matrix is shown below.

$$
B_{i j}=\left[\begin{array}{cccc}
b_{11} & b_{12} & \ldots & b_{1 n} \\
b_{21} & b_{22} & \ldots & b_{2 n} \\
\vdots & \vdots & \vdots & \vdots \\
b_{m 1} & b_{m 2} & \ldots & b_{m n}
\end{array}\right]
$$

Step 2: Normalizing the decision matrix.

The $B_{i j}$ decision matrix is normalized using equation 2 .

$$
t_{i j}=\frac{b_{i j}}{\sum_{i=1}^{m} b_{i j}} \quad j=1,2, \ldots . ., n
$$

Step 3: Calculation of entropy values.

After normalizing the decision matrix, the entropy values for the criteria were calculated using equation (3).

$e_{j}=-h \sum_{i=1}^{m} t_{i j} \ln t_{i j} \quad j=1,2, \ldots ., n$

Where $\mathrm{h}$ is a constant, let $h=(\ln (m))^{-1}$

Step 4: Calculating the degree of diversification.

The degree of divergence of the intrinsic information of each criterion is calculated by using equation (4).

$$
d_{j}=1-e_{j}
$$

Step 5: Calculation of objective weight of criterion

The objective weight for each criterion can be calculated from equation (5).

$w_{j}=\frac{d_{j}}{\sum_{j=1}^{n} d_{j}}$

\subsection{EDAS Method}

The Evaluation Based on Distance from Average Solution (EDAS) method was first developed by Ghorabaee et al. (2015). In this developed method, the average solution is used to evaluate the alternatives. Positive distance average (PDA) and negative distance average (NDA) are two separate measures used to evaluate alternatives. The best alternative is chosen considering these two distances (Ghorabaee et al., 2015: 435-451; Kahraman, et al., 2017: 2; Chatterjee et al., 2018: 192; Adal1 and Tus, 2019: 3) The steps of the EDAS method were as follows (Ghorabaee et al., 2015: 439-440; Chatterjee et al., 2018: 193-195; Mathew and Sahu, 2018: 141-142; Aggarwall et al., 2018: 238-239; Adalı and Tuş, 2019: 4 ; Behzad et al., 2020: 5): 


\section{TÜRKIYE MESLEKI VE SOSYAL BILIMLER DERGISi}

Türkiye Mesleki ve Sosyal Bilimler Dergisi, Ağustos 2021, Yıl: 3, Sayı: 6, 36-49.

Journal of Vocational and Social Sciences of Turkey, Aug 2020, Year: 3, No: 6, 36-49.

Step 1: Creation of decision matrix $(\mathrm{X})$.

$$
X=\left[X_{i j}\right]_{n \times m}=\left[\begin{array}{cccc}
x_{11} & x_{12} & \ldots & x_{1 n} \\
x_{21} & x_{22} & \ldots & x_{2 n} \\
\vdots & \vdots & \vdots & \vdots \\
x_{m 1} & x_{m 2} & \ldots & x_{m n}
\end{array}\right]
$$

Where $X_{i j}$ demonstrates the performance value of $i$ th alternative on $j$ th criterion.

Step 2: Determination of the average solution considering to all criteria.

$$
A V=\left\lfloor A V_{j}\right\rfloor_{1 x m}
$$

Where,

$$
A V_{j}=\frac{\sum_{i=1}^{m} x_{i j}}{m}
$$

Step 3: Calculatin of the PDA and the NDA matrices according to the sort of criteria (cost and benefit).

$$
\begin{aligned}
& P D A=\left\lfloor P D A_{i j}\right\rfloor_{n x m} \\
& N D A=\left\lfloor N D A_{i j}\right\rfloor_{n \times m}
\end{aligned}
$$

If $j$ th criterion is beneficial,

$$
\begin{aligned}
P D A_{i j} & =\frac{\max \left(0,\left(x_{i j}-A V_{j}\right)\right)}{A V_{j}} \\
N D A_{i j} & =\frac{\max \left(0,\left(A V_{j}-x_{i j}\right)\right)}{A V_{j}}
\end{aligned}
$$

And if $j$ th criterion is non-beneficial

$$
\begin{aligned}
P D A_{i j} & =\frac{\max \left(0,\left(A V_{j}-x_{i j}\right)\right)}{A V_{j}} \\
N D A_{i j} & =\frac{\max \left(0,\left(x_{i j}-A V_{j}\right)\right)}{A V_{j}}
\end{aligned}
$$

where $P D A_{i j}$ and $N D A_{i j}$ demonstrate the positive and negative distance of $i$ th alternative from average solution in terms of $j$ th criterion, respectively

Step 4: Calculate the weighted sum of $P D A$ and weighted sum of $N D A$ for all alternatives.

$$
S P_{i}=\sum_{j=1}^{m} w_{j} P D A_{i j}
$$




\section{TÜRKIYE MESLEKI VE SOSYAL BILIMLER DERGISi}

Türkiye Mesleki ve Sosyal Bilimler Dergisi, Ağustos 2021, Yıl: 3, Sayı: 6, 36-49.

Journal of Vocational and Social Sciences of Turkey, Aug 2020, Year: 3, No: 6, 36-49.

$$
S N_{i}=\sum_{j=1}^{m} w_{j} N D A_{i j}
$$

Where $w_{j}$ is the weight of $j$ th criterion.

Step 5: Normalize the $S P$ and $S N$ values for all alternatives.

$$
\begin{aligned}
& N S P_{i}=\frac{S P_{i}}{\max _{i}\left(S P_{i}\right)} \\
& N S N_{i}=1-\frac{S N_{i}}{\max _{i}\left(S N_{i}\right)}
\end{aligned}
$$

Step 6: Calculate the appraisal score (AS) for all alternatives.

$$
A S_{i}=\frac{1}{2}\left(N S P_{i}+N S N_{i}\right)
$$

Where $0 \leq A S_{i} \leq 1$

Step 7: Ranking of the alternatives considering the descending values of AS.

The alternative with the biggest AS value is the best.

\subsection{CODAS Method}

CODAS (Combinative Distance-based Assessment) method was first developed by Ghorabaee et al ., (2016). In the CODAS method, the preference of the alternatives is determined by the Euclidean (Euclidean) and Taksicab (Taxicab) distances (Ghorabaee et al., 2016: 29; Bakır and Alptekin, 2018: 1341). The application steps of the CODAS method were given below (Ghorabaee et al., 2016: 29-30; Badi et al., 2018: 616-617; Mathew and Sahu, 2018: 140-141; Bakır and Alptekin, 2018: 1342-1344; Ulutaş, 2020: 1642-1643):

Step 1: Creating a decision matrix $(\mathrm{X})$ with alternatives and criteria.

$$
X=\left[x_{i j}\right]_{n \times m}=\left[\begin{array}{cccc}
x_{11} & x_{12} & \ldots & x_{1 m} \\
x_{21} & x_{22} & \ldots & x_{2 m} \\
\vdots & \vdots & \vdots & \vdots \\
x_{n 1} & x_{n 2} & \ldots & x_{n m}
\end{array}\right]
$$

Where $x_{i j}\left(x_{i j} \geq 0\right)$ denotes the performance value of $i$ th alternative on $j$ th criterion.

Step 2: Compute the normalized decision matrix.

$$
n_{i j}= \begin{cases}\frac{x_{i j}}{\max _{i} x_{i j}} & \text { if } j \in N_{b} \\ \frac{\min _{i} x_{i j}}{x_{i j}} & \text { if } j \in N_{c}\end{cases}
$$

The values $N_{b}$ and $N_{c}$ in equation (21) express the benefit and criteria, respectively.

Step 3: Compute the weighted normalized decision matrix. 


\section{TÜRKIYE MESLEKI VE SOSYAL BILIMLER DERGISI}

Türkiye Mesleki ve Sosyal Bilimler Dergisi, Ağustos 2021, Yıl: 3, Sayı: 6, 36-49.

Journal of Vocational and Social Sciences of Turkey, Aug 2020, Year: 3, No: 6, 36-49.

This calculation, which is based on multiplying the column elements belonging to the normalized decision matrix with the relevant weight coefficients, is realized with equation (22).

$r_{i j}=w_{j} n_{i j}$

Step 4: Determination of the negative-ideal solution point (NIS).

Using equation (23), the smallest values of the columns in the weighted matrix are selected.

$n s=\left\lfloor n s_{j}\right\rfloor_{1 \times m} \quad n s_{j}=\min _{i} r_{i j}$

Step 5: Calculation the Euclidean distances $\left(E_{i}\right)$ and Taxicab distances $\left(T_{i}\right)$ of alternatives from the negative-ideal solution.

Calculation of ( $\left.E_{i}\right)$ and $\left(T_{i}\right)$ values were shown in equations (24) and (25), respectively.

$$
\begin{aligned}
E_{i} & =\sqrt{\sum_{j=1}^{m}\left(r_{i j}-n s_{j}\right)^{2}} \\
T_{i} & =\sum_{j=1}^{m}\left|r_{i j}-n s_{j}\right|
\end{aligned}
$$

Step 6: Creation of Comparative evaluation matrix.

A Comparative evaluation matrix is created from equation (26).

$$
\begin{aligned}
& R_{a}=\left[h_{i k}\right]_{n \times n} \\
& h_{i k}=\left(E_{i}-E_{k}\right)+\left(\psi\left(E_{i}-E_{k}\right) \times\left(T_{i}-T_{k}\right)\right)
\end{aligned}
$$

Where $k \in\{1,2, \ldots, n\}$ and $\psi$ denotes a threshold function recognizes the equality of the Euclidean and as given equation (27).

$$
\psi(x)= \begin{cases}1, & \text { if }|x| \geq \tau \\ 0, & \text { if }|x| \leq \tau\end{cases}
$$

In this function, $\tau$ is the threshold parameter that can be adjust by the decision-maker. It is recommended to adjust this parameter for between 0,01 and 0,05. If the difference between Euclidean distances of two alternatives is less than $\tau$, these two alternatives are also compared by the Taxicab distance (Ghorabaee et al., 2016: 30; Badi et al., 2018: 617). In this study $\tau$ value was taken 0,02.

Step 7: Calculate the assessment score of each alternatives.

$$
H_{i}=\sum_{k=1}^{n} h_{i k}
$$

By ranking the $H_{i}$ scores of the alternatives in descending order, the alternatives are ranked from the best to the worst.

\section{APPLICATION}

This study was carried out in a firm in the field of software and consultancy in Turkey. The company develops and markets software products such as mobile applications and websites. Entropy, CODAS and EDAS methods were used together to determine the software personnel needed by the company. Criteria weights obtained by entropy method were used in CODAS and EDAS methods. Six 


\section{TÜRKIYE MESLEKI VE SOSYAL BILIMLER DERGISi}

Türkiye Mesleki ve Sosyal Bilimler Dergisi, Ağustos 2021, Yıl: 3, Sayı: 6, 36-49. Journal of Vocational and Social Sciences of Turkey, Aug 2020, Year: 3, No: 6, 36-49.

alternative candidates were evaluated according to six criteria in the study. Microsoft Excel 2016 program was used to apply Entropy, CODAS and EDAS methods. The criteria used in the application were selected by company managers among the criteria commonly used in personnel selection in the literature. (Karabesevic et al., 2015; Kundakc1, 2016; Adal1, 2016; Kenger and Orhan, 2017; Tus and Adal1, 2018; Ulutaş, 2019; Yıldırım et al., 2019; Yalçın and Pehlivan, 2019; Ayçin, 2020). These criteria were expressed in the study as K1 (computer and software skills), K2 (communication skills), K3 (work experience), K4 (teamwork adaptability), K5 (foreign language knowledge) and K6 (problem solving skills), respectively. Nine candidates were applied for software personnel required by the company, and three candidates were not evaluated due to their reference and military duty status. In the application, alternative candidates were expressed as P1, P2..., P6, respectively. In the study, the work experiences of the candidates were evaluated in months. The candidates were evaluated by company officials using a 5-point scale (1: very low, 2: low, 3: medium, 4: high, 5: very high) (Adal1, 2016; Kundakc1, 2016) according to the other five criteria and the results were given in Table 1. The hierarchical structure of the study is shown in Figure 1.

Figure 1. The Hierarchical Structure of The Study

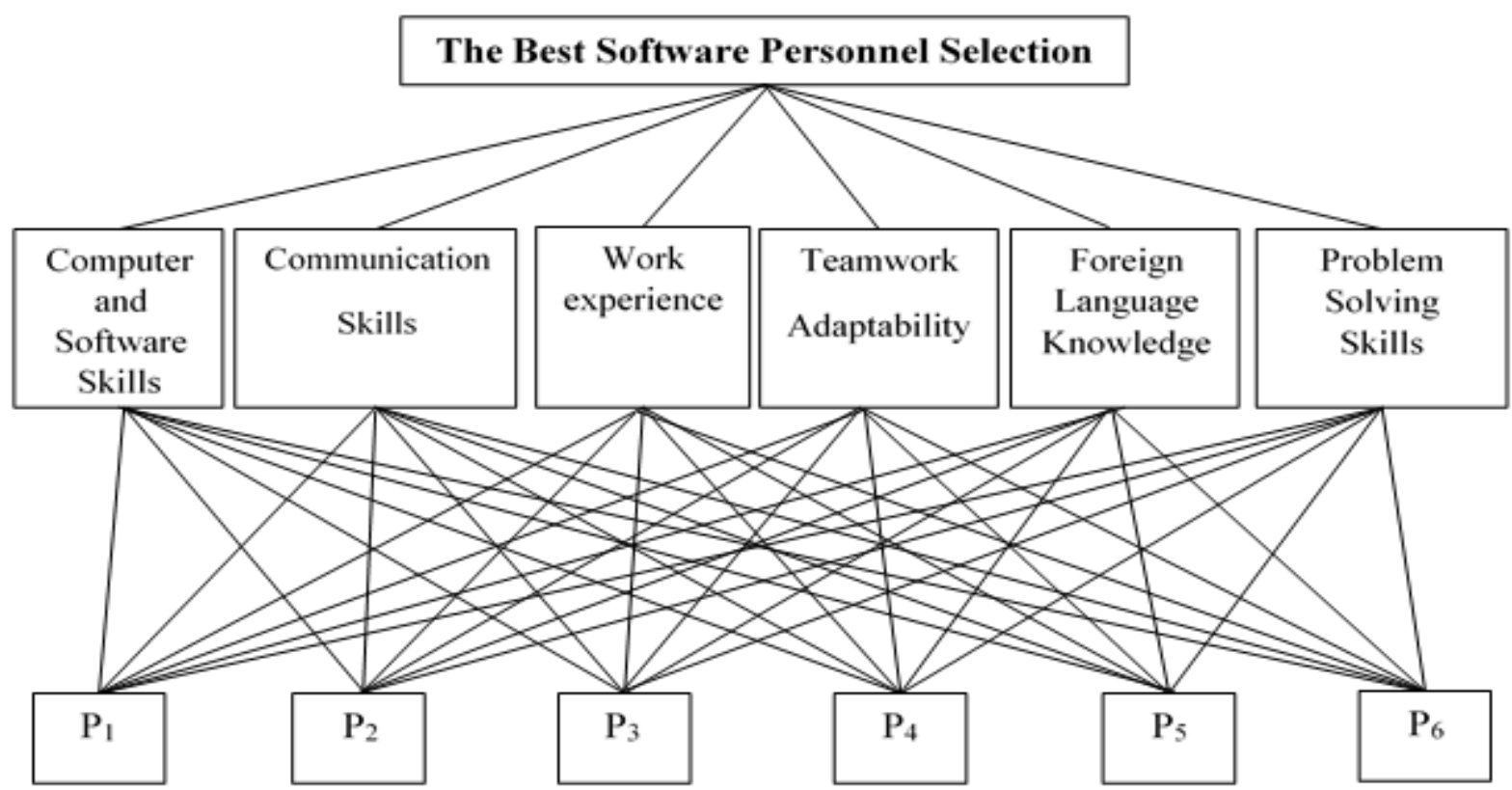

\section{RESULTS AND DISCUSSION}

In the study, the weights of the criteria were calculated using the entropy method. Alternatives were ranked by comparing the EDAS and CODAS method results. Entropy, EDAS and CODAS method results were given below.

\subsection{Results of Entropy Method}

First, the decision matrix was created as in Table 1. Alternatives have been respectively expressed as $\mathrm{P} 1, \mathrm{P} 2, \ldots ., \mathrm{P} 6$ and criteria as $\mathrm{K} 1, \mathrm{~K} 2, \ldots ., \mathrm{K} 6$ in Table 1. 


\section{TÜRKIYE MESLEKI VE SOSYAL BILIMLER DERGISi}

Türkiye Mesleki ve Sosyal Bilimler Dergisi, Ağustos 2021, Yıl: 3, Sayı: 6, 36-49.

Journal of Vocational and Social Sciences of Turkey, Aug 2020, Year: 3, No: 6, 36-49.

Table 1. Decision Matrix

\begin{tabular}{|c|c|c|c|c|c|c|}
\hline \multirow{3}{*}{ Alternatives } & \multicolumn{6}{|l|}{ Criteria } \\
\hline & $\begin{array}{l}\text { Computer and } \\
\text { software skills }\end{array}$ & $\begin{array}{l}\text { Communication } \\
\text { skills }\end{array}$ & $\begin{array}{l}\text { Work } \\
\text { experience }\end{array}$ & $\begin{array}{l}\text { Teamwork } \\
\text { adaptability }\end{array}$ & \begin{tabular}{|l|} 
Foreign \\
language \\
knowledge
\end{tabular} & $\begin{array}{l}\text { Problem solving } \\
\text { skills }\end{array}$ \\
\hline & $\mathrm{K} 1$ & $\mathrm{~K} 2$ & K3 & K4 & K5 & K6 \\
\hline $\mathrm{P} 1$ & 4 & 4 & 17 & 4 & 3 & 5 \\
\hline $\mathrm{P} 2$ & 4 & 3 & 23 & 4 & 4 & 4 \\
\hline P3 & 3 & 4 & 15 & 3 & 5 & 3 \\
\hline $\mathrm{P} 4$ & 5 & 4 & 19 & 4 & 4 & 4 \\
\hline $\mathrm{P} 5$ & 3 & 4 & 14 & 4 & 4 & 4 \\
\hline P6 & 4 & 3 & 21 & 4 & 5 & 4 \\
\hline
\end{tabular}

After the decision matrix was created, the normalized decision matrix was obtained by using equation (2). Later, the decision matrix was normalized, Entropy values and criterion weights were calculated. These calculated values were given in Table 2 .

Table 2. Entropy Values and Criteria Weights

\begin{tabular}{|l|l|l|l|l|l|l|}
\hline Results & $\mathrm{K} 1$ & $\mathrm{~K} 2$ & $\mathrm{~K} 3$ & $\mathrm{~K} 4$ & $\mathrm{~K} 5$ & $\mathrm{~K} 6$ \\
\hline$e_{j}$ & 0,991 & 0,995 & 0,991 & 0,997 & 0,992 & 0,994 \\
\hline$d_{j}=1-e_{j}$ & 0,009 & 0,005 & 0,009 & 0,003 & 0,008 & 0,006 \\
\hline$w_{j}$ & 0,231 & 0,123 & 0,221 & 0,073 & 0,200 & 0,152 \\
\hline
\end{tabular}

It can be said that the criterion with the highest weight is K1. Criteria weights obtained as a result of the Entropy method were used in EDAS and CODAS methods.

\subsection{Results of EDAS Method}

EDAS method was applied to the decision matrix given in Table 1. Average solutions of the criteria were calculated with equation (8). The average solutions $\left(A V_{j}\right)$ of the criteria were given in Table 3.

Table 3. Average Solutions of The Criteria

\begin{tabular}{|l|l|l|l|l|l|l|}
\hline Criteria & K1 & K2 & K3 & K4 & K5 & K6 \\
\hline$A V_{j}$ & 3,833 & 3,667 & 18,167 & 3,833 & 4,167 & 4,000 \\
\hline
\end{tabular}

PDA and NDA values were calculated after calculating the average solutions of the criteria. Table 4 shows the EDAS method results and the ranking of the alternatives.

Table 4. Ranking of The Alternatives According to The EDAS Method

\begin{tabular}{|l|l|l|l|l|l|l|}
\hline Alternatives & $S P_{i}$ & $S N_{i}$ & $N S P_{i}$ & $N S N_{i}$ & $A S_{i}$ & Rank \\
\hline P1 & 0,062 & 0,070 & 0,658 & 0,506 & 0,582 & 4 \\
\hline P2 & 0,072 & 0,030 & 0,760 & 0,786 & 0,773 & 3 \\
\hline P3 & 0,051 & 0,142 & 0,541 & 0,000 & 0,271 & 5 \\
\hline P4 & 0,095 & 0,008 & 1,000 & 0,944 & 0,972 & 1 \\
\hline P5 & 0,014 & 0,109 & 0,152 & 0,235 & 0,193 & 6 \\
\hline P6 & 0,088 & 0,022 & 0,926 & 0,843 & 0,884 & 2 \\
\hline
\end{tabular}




\section{TÜRKIYE MESLEKI VE SOSYAL BILIMLER DERGISi}

Türkiye Mesleki ve Sosyal Bilimler Dergisi, Ağustos 2021, Yıl: 3, Sayı: 6, 36-49. Journal of Vocational and Social Sciences of Turkey, Aug 2020, Year: 3, No: 6, 36-49.

\subsection{Results of CODAS Method}

The CODAS method has been applied to the decision matrix given in Table 1. The normalized decision matrix, which has been obtained using equation (21), was shown in Table 5.

Table 5. Normalized Decision Matrix

\begin{tabular}{|l|l|l|l|l|l|l|}
\hline & K1 & K2 & K3 & K4 & K5 & K6 \\
\hline P1 & 0,8 & 1 & 0,73913 & 1 & 0,6 & 1 \\
\hline P2 & 0,8 & 0,75 & 1 & 1 & 0,8 & 0,8 \\
\hline P3 & 0,6 & 1 & 0,65217 & 0,75 & 1 & 0,6 \\
\hline P4 & 1 & 1 & 0,82609 & 1 & 0,8 & 0,8 \\
\hline P5 & 0,6 & 1 & 0,6087 & 1 & 0,8 & 0,8 \\
\hline P6 & 0,8 & 0,75 & 0,91304 & 1 & 1 & 0,8 \\
\hline
\end{tabular}

Table 6 shows the results of the CODAS method and the ranking of the alternatives.

Table 6. Ranking of the Alternatives According to the CODAS Method

\begin{tabular}{|l|l|l|l|l|}
\hline Alternatives & $E_{i}$ & $T_{i}$ & $H_{i}$ & Rank \\
\hline P1 & 0,08902 & 0,18465 & $-0,05539$ & 4 \\
\hline P2 & 0,11170 & 0,22129 & 0,08074 & 3 \\
\hline P3 & 0,08645 & 0,12062 & $-0,07073$ & 5 \\
\hline P4 & 0,12102 & 0,25981 & 0,13679 & 1 \\
\hline P5 & 0,06170 & 0,11939 & $-0,21901$ & 6 \\
\hline P6 & 0,11976 & 0,24215 & 0,12918 & 2 \\
\hline
\end{tabular}

\subsection{Discussion}

As a result of the study, 6 alternative candidates were ranked according to EDAS and CODAS methods. A Comparison of the alternatives according to EDAS and CODAS methods can be seen in Table 7.

Table 7. Comparison of The Ranking Results

\begin{tabular}{|l|l|l|}
\hline Alternatives & EDAS & CODAS \\
\hline P1 & 4 & 4 \\
\hline P2 & 3 & 3 \\
\hline P3 & 5 & 5 \\
\hline P4 & 1 & 1 \\
\hline P5 & 6 & 6 \\
\hline P6 & 2 & 2 \\
\hline
\end{tabular}

According to the EDAS and CODAS method results, the ranking of the alternatives is $\mathrm{P} 4>\mathrm{P} 6>\mathrm{P} 2>$ $\mathrm{P} 1>\mathrm{P} 3>\mathrm{P} 5$.

\section{CONCLUSION}

Personnel selection is a complex decision-making process in which multiple criteria and alternatives must be considered simultaneously. In general, MCDM methods are used in such selection problems where there are more than one criteria and alternatives. The personnel selection problem is a MCDM problem in which the best candidate is selected from among the candidates.

In this study, Entropy, EDAS and CODAS methods were used together for the selection of software personnel of a firm in the software and consultancy industry. In the first stage of the study, the criteria were weighted with the entropy method and it was determined that the criteria with the highest weight were computer and software skills, work experience, and foreign language knowledge, respectively. These criteria were followed by problem solving skill, communication skill, and teamwork 
Türkiye Mesleki ve Sosyal Bilimler Dergisi, Ağustos 2021, Yıl: 3, Sayı: 6, 36-49. Journal of Vocational and Social Sciences of Turkey, Aug 2020, Year: 3, No: 6, 36-49.

adaptability criteria. To be able to make a selection among alternative personnel, the application was continued with the EDAS and CODAS methods. Criteria weights obtained by entropy method were used in EDAS and CODAS methods. As a result of the application of the CODAS and EDAS methods, the ranking of alternative personnel was made. According to the results of the study, the best alternative candidate for the company was determined as the P4 candidate. According to the EDAS and CODAS method results, the ranking of the alternatives was P4> P6> P2> P1> P3> P5.

There are some limitations to this study. One of the limitations of this study is that it was carried out in Turkey and in the software industry. Another limitation is the use of six alternatives and six criteria in the study. Another important limitation is that only two different MCDM methods were compared in the study. Similar personnel selection problems can be solved with other MCDM methods in future studies. Applications to be carried out in different fields by using EDAS, CODAS and other MCDM methods together maybe another subject of study. Different criteria and alternatives can be used in future studies for personnel selection.

\section{REFERENCES}

Adalı E.A. (2016). "Personnel Selection In Health Sector With EVAMIX and TODIM Methods". Alphanumeric Journal, 4(2), 69-84. https://doi.org/10.17093/aj.2016.4.2.5000194528

Adalı, E.A. and Tuş, A. (2019). "Hospital site selection with distance-based multi-criteria decision-making methods". International Journal of Heathcare Management, 1-11. https://doi.org/10.1080/20479700.2019.1674005

Afshari, A.R., Nikolic, M. and Cockalo, D. (2014). "Application of fuzzy decision making for personnel selection problem-a review". Journal of Engineering Management and Competitiveness (JEMC), 4(2), 68-77.

Aggarwal, A., Choudhary, C. and Mehrotra, D. (2018). "Evaluation of Smartphones in Indian Market using EDAS”. Procedia Computer Science, 132, 236-243. https://doi.org/10.1016/j.procs.2018.05.193

Alguliyev, R.M., Alguliyev, R.M. and Mahmudova, R.S. (2015). "Multicriteria Personnel Selection by the Modified Fuzzy VIKOR Method". Scientific World Journal, 2015, 1-16. http://dx.doi.org/10.1155/2015/612767

Ayçin, E. (2020). "Personel Seçim Sürecinde CRITIC ve MAIRCA Yöntemlerinin Kullanılması". The Business Journal, 1(1), 1-12. https://isletmedergi.org/index.php/isletme/article/view/4

Aytekin, A., Karamaşa, Ç. (2017). "Analyzing Financial Performance of Insurance Companies Traded In BIST via Fuzzy Shannon's Entropy Based Fuzzy TOPSIS Methodology”. Alphanumeric journal, 5(1), 71-84. https://doi.org/10.17093/alphanumeric.323832

Badi, I., Ballem, M. A. And Shetwan, A. G. (2018). "Site selection of desalination plant in Libya by using Combinative Distance-based Assessment (CODAS) Method". International Journal for Quality Research, 12(3), 609-624. DOI: 10.18421/IJQR12.03-04

Bakır, M. and Alptekin, N. (2018). "A new approach in service quality assesment: An application on airlines through CODAS method". Business \& Management Studies: An International Journal, 6(4), 1336-1353. http://dx.doi.org/10.15295/bmij.v6i4.409

Behzad, M., Zolfani, S.H., Pamucar, D., and Behzad, M. (2020). "A comparative assessment of solid waste management performance in the Nordic countries based on BWM-EDAS". Journal of Cleaner Production, 266, 1-11. https://doi.org/10.1016/j.jclepro.2020.122008

Chatterjee, P., Banerjee, A., Mondal, S., Boral, S. and Chakraborty, S. (2018). "Development of a Hybrid MetaModel for Material Selection Using Design of Experiments and EDAS Method". Engineering Transactions, 66(2), 187-207. http://et.ippt.pan.pl/index.php/et/article/view/812

Dehdasht G, Ferwati M.S., Zin R.M. and Abidin N.Z. (2020). "A hybrid approach using entropy and TOPSIS to select key drivers for a successful and sustainable lean construction implementation". PLoS ONE, 15(2), 1-32. https://doi.org/10.1371/journal.pone.0228746

Ecer, F., Pamucar, D., Mardani, A. and Alrasheedi, M. (2021). "Assessment of renewable energy resources using new interval rough number extension of the level based weight assessment and combinative distancebased assessment". Renewable Energy, 170, 1156-1177. https://doi.org/10.1016/j.renene.2021.02.004

Ersoy, Y. (2021). "Performance Evaluation in Distance Education by Using Data Envelopment Analysis (DEA) and TOPSIS Methods". Arabian Journal for Science and Engineering, 46(2), 1803-1817. https://doi.org/10.1007/s13369-020-05087-0 


\section{TÜRKIYE MESLEKI VE SOSYAL BILIMLER DERGISI}

Türkiye Mesleki ve Sosyal Bilimler Dergisi, Ağustos 2021, Yıl: 3, Sayı: 6, 36-49. Journal of Vocational and Social Sciences of Turkey, Aug 2020, Year: 3, No: 6, 36-49.

Ghorabaee, M.K., Zavadskas, E.K., Olfat, L. and Turskis, Z. (2015). "Multi-Criteria Inventory Classification Using a New Method of Evaluation Based on Distance from Average Solution (EDAS) ". INFORMATICA, 26(3), 435-451. https://doi.org/10.15388/Informatica.2015.57

Ghorabaee, M. K., Zavadskas, E. K., Turskis, Z., and Antucheviciene, J. (2016). "A New Combinative DistanceBased Assessment (CODAS) Method For Multi-Criteria Decision Making”. Economic Computation and Economic Cybernetics Studies and Research, 3(50), 25-44. http://www.ecocyb.ase.ro/Articles2016_3.htm

İçigen, E. T., and Çetin, E. İ. (2018). "Personel Selection By Using AHP Based TOPSIS Method for Accomodation Enterprises". Balkan Journal of Social Sciences, 7(13), 179-187. https://dergipark.org.tr/tr/pub/bsbd/issue/34559/337848

Kahraman C, Ghorabaee M.K., Zavadskas E.K., Onar, S.C., Yazdani, M. and Oztaysi, B. (2017). "Intuitionistic fuzzy EDAS method: an application to solid waste disposal site selection". Journal of Environmental Engineering and Landscape Management, 25(1), 1-12. https://doi.org/10.3846/16486897.2017.1281139

Kaplinski, O., Peldschus, F., Nazarko, J., Kaklauskas, A. Baušys, R. (2019). "MCDM, operational research and sustainable development in the trans-border Lithuanian-German- Polish co-operation". Engineering Management in Production and Services, 11(2), 7-18. https://doi.org/10.2478/emj-2019-0007

Karabasevic, D., Stanujkic, D., and Urosevic, S. (2015). "The MCDM Model for Personnel Selection Based on SWARA and ARAS Methods". Management, (77), 43-52. DOI: 10.7595/management.fon.2015.0029

Karabesevic, D., Zavadskas, E.K., Stanujkic, D., Popovic, G. and Brzakovic, M. (2018). "An approach to personnel selection in the IT industry based on the EDAS method". Transformantions in Business \& Economics, 17(2), 54-65.

Kenger, M.D. and Organ, A. (2017). “Assessment of Bank Personnel Selection by Using Multiple Cirteria Decision Making Method Entropy Based Aras”. Adnan Menderes University Journal of Social Sciences Institute, 4(4), 152-170. https://doi.org/10.30803/adusobed.336215

Korkmaz, O. (2019). "Personel selection method based on TOPSIS multi-criteria decision-making method". International Journal of Economics and Administrative Studies, 23, 1-16. https://doi.org/10.18092/ulikidince.468486

Kundakc1, N. (2016). "Personnel selection with grey relational analysis". Management Science Letters, 6(5), 351-360. DOI: $10.5267 /$ j.msl.2016.3.002

Madenoğlu, F.S. (2020). "Personnel Selection By Using Fuzzy Hybrid Multi Criteria Decision Making Methodology". Journal of Social Sciences of Mus Alparslan University, 8(3), 953-962. https://dergipark.org.tr/en/pub/anemon/issue/54825/645838

Mardani, A., Jusoh, A. Nor, K.M.D., Kahalifah, Z., Zakwan, N. and Valipour, A. (2015) "Multiple criteria decision-making techniques and their applications - a review of the literature from 2000 to 2014", Economic Research-Ekonomska Istraživanja, $\quad 28(1), \quad$ 516-571. https://doi.org/10.1080/1331677X.2015.1075139

Mathew, M. and Sahu, S. (2018). "Comparison of new multi-criteria decision making methods for matiral handling equipment selection”. Management Science Letters, 8(3), 139-150. DOI: $10.5267 /$ j.msl.2018.1.004

Nalbant, K.G. and Ozdemir, Y. (2018). "Personnel Selection Using Fuzzy VIKOR Methodology”. International Journal of Management Science, 5(2), 10-17.

Rezaei, J. (2015). “A Systematic Review of Multi-criteria Decision-making Applications in Reverse Logistics”. Transportation Research Procedia, 10, 766-776. doi: 10.1016/j.trpro.2015.09.030

Samanlioglu, F., Taskaya, Y. E., Gulen, U. C., \& Cokcan, O. (2018). “A fuzzy AHP-TOPSIS-based group decision-making approach to IT personnel selection". International Journal of Fuzzy Systems, 20(5), 1576-1591. https://doi.org/10.1007/s40815-018-0474-7

Soba, M., Ersoy, Y., Altınay, A.T., Erkan, B. and Şik, E. (2020). “Application of Multiple Criteria DecisionMaking Methods in Assignment Place Selection”. Mathematical Problems in Engineering, 2020, 1-13. https://doi.org/10.1155/2020/6748342

Taş, A. ve Karataş, P.Ç. (2021). "Analysis of Qualified Personnel Selection in Software Sector With Neutrosophic AHP And TOPSIS Methods". Journal of Business Researc-Turk, 13(1), 969-979. https://doi.org/10.20491/isarder.2021.1178

Tuş, A. and Adalı, E.A. (2018). "Personnel Assessment with CODAS and PSI Methods". Alphanumeric Journal, 6(2), 243-256. https://doi.org/10.17093/alphanumeric.432843

Ulutaş, A. (2019). "Personnel Selection with Entropy and MABAC Methods". OPUS International Journal of Society Researches, 13(19), 1552-1573. https://doi.org/10.26466/opus.580456 


\section{TÜRKIYE MESLEKI VE SOSYAL BILIMLER DERGISi}

Türkiye Mesleki ve Sosyal Bilimler Dergisi, Ağustos 2021, Yıl: 3, Sayı: 6, 36-49.

Journal of Vocational and Social Sciences of Turkey, Aug 2020, Year: 3, No: 6, 36-49.

Ulutaş, A., Özkan, A. M. and Tağraf, H. (2018). "Personnel Selection By Using Fuzzy Analytic Hierarchy Process and Fuzzy Grey Relational Analysis”. Electronic Journal of Social Sciences, 17(65), $223-232$. https://doi.org/10.17755/esosder.317209

Ulutaş, A. (2020). "SWARA Based CODAS Method for Cargo Company Selection". MANAS Journal of Social Studies, 9(3),1640-1647. https://doi.org/10.33206/mjss.559351

Yalçın, N., and Pehlivan, N.P. (2019). "Application of the Fuzzy CODAS Method Based on Fuzzy Envelopes for Hesitant Fuzzy Linguistic Term Sets: A Case Study on a Personnel Selection Problem”. Symmetry, 11(4), 1-27. https://doi.org/10.3390/sym11040493

Yeni, F.B. and Özçelik, G. (2019). "Interval-Valued Atanassov Intuitionistic Fuzzy CODAS Method for Multi Criteria Group Decision Making Problems". Group Decision and Negotiation, 28, 433-452. https://doi.org/10.1007/s10726-018-9603-9

Yıldırım, B. I., Uysal, F., and Ilgaz, A. (2019). "Personnel Selection in Airline Companies: An Application with ARAS Method". Journal of Süleyman Demirel University Institute of Social Sciences, 2(33), 219-231. https://dergipark.org.tr/tr/pub/sbe/issue/41368/559124

Wang, T. C. and Lee, H. D. (2009). "Developing A Fuzzy TOPSIS Approach Based on Subjective Weights and Objective Weights". Expert Systems with Applications, 36(5), 8980-8985. https://doi.org/10.1016/j.eswa.2008.11.035

Wang, E., Alp, N., Shi, J., Wang, C., Zhang, X. and Chen, H. (2017). "Multi-criteria building energy performance benchmarking through variable clustering based compromise TOPSIS with objective entropy weighting”. Energy, 125, 197-210. https://doi.org/10.1016/j.energy.2017.02.131 